\title{
Operative Treatments for Acromegaly: Comparison of Transsphenoidal Cryogenic and Microsurgical Hypophysectomy
}

\author{
Akinori Kondo, Hajime HandA*, Hiroshi MatsumurA** \\ and Yasumasa MaKITA*** \\ Department of Neurosurgery, Fukui Red Cross Hospital,Fukui, \\ Department of Neurosurgery, Kyoto University Medical School, Kyoto, \\ Department of Neurosurgery, Kansai Medical School, Osaka** \\ and Department of Neurosurgery, Tenri Hospital, Tenri, Japan***
}

\section{Summary}

\begin{abstract}
Surgical treatments for acromegaly both by transnasal transsphenoidal cryogenic ablation and by transsphenoidal microsurgical dissection were carried out in two different series and the postoperative follow-up results of $\mathrm{HGH}$ level and other pituitary hormones of both groups were compared and discussed for the first time. There were no significant differences in postoperative changes of pituitary functions between each operative method, whereas as for long-term satisfactory lowering of HGH level, i.e. radical cure of acromegaly, the microsurgical treatment was concluded as more reliable than cryogenic ablation of pituitary adenomas.
\end{abstract}

Key words: Acromegaly, pituitary hormones, cryogenic hypophysectomy, microhypophysectomy

\section{Introduction}

Acromegaly is caused by hypersecretion of human growth hormone $(\mathrm{HGH})$ from the functioning pituitary adenomas. It is obvious, therefore, that the treatment of this disease should be the complete removal or eradication of the pituitary tumor. The authors performed operations for acromegaly both by transnasal, transsphenoidal cryogenic surgery and by transsphenoidal microsurgery in two different series. Long-term follow-up study encompassing 19 patients ( 9 patients by cryosurgery and 10 by microsurgery) whose clinical and endocrinological data, such as an assessment of perioperative change in $\mathrm{HGH}$ or other pituitary hormones, were available.

There is still some controversial opinions concerning the effectiveness of reduction in $\mathrm{HGH}$, subsequent preservation of normal function of the pituitary gland, and operative complications, ${ }^{22)}$ between these two operative methods.

Detailed reports which concern postoperative follow-up evaluation of $\mathrm{HGH}$ and other pituitary hormones after microsurgical dissections are, however, scarce in the literature and no comparison of changes in postoperative functions after applying these two different operative methods have been made. The purpose of this paper is to compare and discuss the follow-up data of both of these operative treatments for acromegaly.

\section{Operative Methods}

Cryosurgery: The ablation of functioning pituitary tumor by deep freezing was introduced in this field by Cooper in $1963^{1)}$ and use via transsphenoidal route by Rand et al. ${ }^{2,20}$ The duration of freezing and the number of lesions made were variable in each case depending on the size of the sella turcica. Our method is the same as that of Rand et al. and the details are described elsewhere. ${ }^{8}$

Microsurgery: In 1907, transsphenoidal approach to the sella was first introduced by Schloffer and it was developed by Hirsch. ${ }^{13)}$ For neurosurgeons, Cushing's subnasal midline rhinoseptal approach is still the most simple, rapid and convenient. Moreover, the midline 
proach was enhanced by modern technical adjuvants such as an image intensifier and binocular surgical microscope. ${ }^{9,11)}$ Our technique is similar to that devised by Hardy and other pioneers. ${ }^{7,10,12)}$

\section{Endocrinological Study}

HGH was measured by radioimmunoassay. Other assessments before and after operative treatments included estimation of plasmacortisol and urinary 17-hydroxycorticosteroids and 17-ketosteroids. Thyroid functions and urinary gonadotropins were also assessed.

\section{Clinical Cases and Operative Results}

A) Transsphenoidal stereotaxic cryogenic ablation

The overall results are summarized in Tables 1 and 2.
Nine patients were available for clinical and endocrinological follow-up whose surgical intervention was performed at the Department of Neurosurgery, Kyoto University Hospital since 1967. In cases of this series, the suprasellar extension of the tumor was rare or minimum even when it existed. Age of the patients ranged from 25 to 52 years and males outnumbered female by 8 to 1 . All patients showed decreased sexual libido and one female was amenorrheal before surgery.

Preoperative fasting $\mathrm{HGH}$ levels ranged from 20.0 to $288.0 \mathrm{ng} / \mathrm{ml}$ (average $91.9 \mathrm{ng} / \mathrm{ml}$ ) and all the cases showed no or abnormal responses of HGH to glucose tolerance test (GTT) and insulin tolerance test (ITT), except for 2 cases who showed partly normal responses (Cases 5 and 7). Preoperative pituitary functions were all in the normal range except for one who revealed slightly reduced values (Case 9).

Postoperative follow-up periods were between

Table 1 Data of clinical features, plasma $\mathrm{HGH}$ values, response of HGH to GTT or ITT and other pituitary functions before transsphenoidal cryoablation. The term "partly responsive" to GTT or ITT (Cases 5, 7) means that HGH value was normally responsive either to GTT or ITT. Normal range of other pituitary hormones means that almost all pituitary functions were normal except for $\mathbf{H G H}$.

\begin{tabular}{|c|c|c|c|c|c|c|c|}
\hline No. & Name & Age & Sex & $\begin{array}{c}\text { Clinical } \\
\text { manifestations }\end{array}$ & $\underset{(\mathrm{ng} / \mathrm{ml})}{\mathrm{HGH}}$ & $\begin{array}{c}\text { GTT } \\
\text { ITT }(\mathrm{HGH})\end{array}$ & $\begin{array}{l}\text { Other } \\
\text { pituitary } \\
\text { functions }\end{array}$ \\
\hline 1. & K.M. & 38 & $\mathrm{~m}$ & $\begin{array}{l}\text { acromegalic } \\
\text { D.M. }(+)\end{array}$ & 80.0 & $\begin{array}{l}\text { poor } \\
\text { response }\end{array}$ & $\begin{array}{l}\text { normal } \\
\text { range }\end{array}$ \\
\hline 2. & Y.T. & 27 & $\mathrm{~m}$ & $\begin{array}{l}\text { acromegalic } \\
\text { D.M. ( - ) } \\
\text { hypertensive }\end{array}$ & 288.0 & $\begin{array}{l}\text { no normal } \\
\text { response }\end{array}$ & $\begin{array}{l}\text { normal } \\
\text { range }\end{array}$ \\
\hline 3. & A.D. & 32 & $\mathrm{~m}$ & $\begin{array}{l}\text { acromegalic } \\
\text { D.M. (-t-) } \\
\text { hypertensive }\end{array}$ & 114.0 & $\begin{array}{l}\text { no normal } \\
\text { response }\end{array}$ & $\begin{array}{l}\text { normal } \\
\text { range }\end{array}$ \\
\hline 4. & Y.M. & 25 & $\mathrm{~m}$ & $\begin{array}{l}\text { acromegalic } \\
\text { hypertensive }\end{array}$ & 25.6 & $\begin{array}{r}\text { no normal } \\
\text { response }\end{array}$ & $\begin{array}{l}\text { normal } \\
\text { range }\end{array}$ \\
\hline 5. & K.F. & 41 & $\mathrm{~m}$ & $\begin{array}{l}\text { acromegalic } \\
\text { D.M. ( - ) } \\
\text { hypertensive }\end{array}$ & 46.2 & $\begin{array}{l}\text { partly } \\
\text { normal } \\
\text { response }\end{array}$ & $\begin{array}{l}\text { normal } \\
\text { range }\end{array}$ \\
\hline 6. & E.T. & 25 & $\mathrm{~m}$ & $\begin{array}{l}\text { acromegalic } \\
\text { hypertensive }\end{array}$ & 65.0 & $\begin{array}{l}\text { no normal } \\
\text { response }\end{array}$ & $\begin{array}{l}\text { normal } \\
\text { range }\end{array}$ \\
\hline 7. & R.N. & 52 & $\mathrm{~m}$ & $\begin{array}{l}\text { acromegalic } \\
\text { hypertensive }\end{array}$ & 20.0 & $\begin{array}{l}\text { partly } \\
\text { normal } \\
\text { response }\end{array}$ & $\begin{array}{l}\text { normal } \\
\text { range }\end{array}$ \\
\hline 8. & H.T. & 31 & f & $\begin{array}{l}\text { acromegalic } \\
\text { D.M. }(+) \\
\text { amenorrheal }\end{array}$ & 200.0 & $\begin{array}{l}\text { no normal } \\
\text { response }\end{array}$ & $\begin{array}{l}\text { normal } \\
\text { range }\end{array}$ \\
\hline 9. & K.K. & 36 & $\mathrm{~m}$ & $\begin{array}{l}\text { acromegalic } \\
\text { D.M. }\left(t^{-}\right)\end{array}$ & 43.0 & $\begin{array}{l}\text { no normal } \\
\text { response }\end{array}$ & $\begin{array}{l}\text { slightly } \\
\text { reduced }\end{array}$ \\
\hline
\end{tabular}

D.M.: Diabetes mellitus 
Table 2 Data of postoperative changes in $\mathrm{HGH}$ and other pituitary functions after transsphenoidal cryoablation. The term "partly poor responsive" to GTT or ITT (Cases 3, 5) means that HGH value was poorly responsive to either GTT or ITT. Operative complications and histology of tumors are also described.

\begin{tabular}{|c|c|c|c|c|c|c|c|}
\hline No. & Name & $\begin{array}{l}\text { Clinical } \\
\text { remissions }\end{array}$ & $\begin{array}{l}\mathrm{HGH} \\
(\mathrm{ng} / \mathrm{ml})\end{array}$ & $\begin{array}{c}\text { GTT } \\
\text { ITT(HGH) }\end{array}$ & $\begin{array}{l}\text { Other } \\
\text { pituitary } \\
\text { functions }\end{array}$ & $\begin{array}{l}\text { Complica- } \\
\text { tions }\end{array}$ & Histology \\
\hline 1. & K.M. & $\begin{array}{l}\text { yes, but } \\
\text { recurred } \\
5 \text { yrs later }\end{array}$ & 11.0 & $\begin{array}{l}\text { no normal } \\
\text { response }\end{array}$ & preserved & no & not verified \\
\hline 2. & Y.T. & $\begin{array}{l}\text { yes, slightly } \\
\text { hypertensive } \\
\text { D.M. }( \pm)\end{array}$ & 13.6 & $\begin{array}{l}\text { poor } \\
\text { response }\end{array}$ & preserved & no & acidophilic \\
\hline 3. & A.D. & $\begin{array}{l}\text { yes } \\
\text { D.M. }(-) \\
\text { hypertensive }\end{array}$ & 5.0 & $\begin{array}{l}\text { partly } \\
\text { poor } \\
\text { response }\end{array}$ & preserved & $\begin{array}{l}\text { D.I. }(+) \\
\text { transient }\end{array}$ & acidophilic \\
\hline 4. & Y.M. & yes & 5.7 & $\begin{array}{l}\text { no normal } \\
\text { response }\end{array}$ & $\begin{array}{l}\text { slightly } \\
\text { reduced }\end{array}$ & no & not verified \\
\hline 5. & K.F. & $\begin{array}{l}\text { yes } \\
\text { hypertension }(-) \\
\text { D.M. (-) }\end{array}$ & 17.6 & $\begin{array}{l}\text { partly } \\
\text { poor } \\
\text { response }\end{array}$ & preserved & no & $\begin{array}{l}\text { mostly } \\
\text { acidophilic }\end{array}$ \\
\hline 6. & E.T. & $\begin{array}{l}\text { yes, partially, } \\
\text { hypertensive }\end{array}$ & 42.6 & $\begin{array}{l}\text { no normal } \\
\text { response }\end{array}$ & preserved & no & acidophilic \\
\hline 7. & R.N. & $\begin{array}{l}\text { yes } \\
\text { hypertension }(-)\end{array}$ & 5.0 & $\begin{array}{l}\text { no normal } \\
\text { response }\end{array}$ & $\begin{array}{l}\text { slightly } \\
\text { reduced }\end{array}$ & $\begin{array}{l}\text { D.I. }(+) \\
\quad \text { transient }\end{array}$ & not verified \\
\hline 8. & H.T. & $\begin{array}{l}\text { yes } \\
\text { D.M. }(-) \\
\text { menses }(+)\end{array}$ & 4.8 & $\begin{array}{l}\text { no normal } \\
\text { response }\end{array}$ & preserved & $\begin{array}{l}\text { nasal } \\
\text { bleeding }\end{array}$ & not verified \\
\hline 9. & K.K. & $\begin{array}{l}\text { yes } \\
\text { D.M. }( \pm)\end{array}$ & 8.7 & $\begin{array}{l}\text { no normal } \\
\text { response }\end{array}$ & $\begin{array}{l}\text { remained } \\
\text { unchanged }\end{array}$ & $\begin{array}{l}\text { D.I. }(+) \\
\text { transient }\end{array}$ & not verified \\
\hline
\end{tabular}

D.I.: Diabetes insipidus

D.M.: Diabetes mellitus

1 and 6 years (average 26 months). Almost all the patients had clinical reversal of their acromegalic state after the surgery but postoperative HGH levels were varied between 4.8 and 42.6 $\mathrm{ng} / \mathrm{ml}$ during follow-up periods. In 3 cases, $\mathrm{HGH}$ level was less than $5 \mathrm{ng} / \mathrm{ml}$, in 2 cases, between 5 and $10 \mathrm{ng} / \mathrm{ml}$ and in the remaining 4 cases, more than $10 \mathrm{ng} / \mathrm{ml}$ in follow-up results. Two of 4 cases whose $\mathrm{HGH}$ level was still high one year after the surgery rejected re-cryoablation since their clinical manifestations improved. Three cases out of 9 showed a drop in $\mathrm{HGH}$ level to less than $10 \mathrm{ng} / \mathrm{ml}$ within a week but in 2 cases HGH level was gradually lowered after the surgery. The longest interval was about 5 years (Fig. 1). None of the cases showed normal responses to GTT or ITT, except for 2 cases (Cases 3 and 5) who displayed partly normal responses. Postoperative pituitary functions were preserved in 6 cases, became slightly reduced in 2 cases, and remained slightly reduced in one case (Case 9) even after the surgery. In the female case (Case 8), menses returned 2 months after the surgery. Transient diabetes insipidus occurred in 3 cases and severe epistaxis in one case. One case (Case 1) recurred about 5 years after surgery.

\section{Brief review of recurred case after cryosurgery}

This case who recurred after cryosurgery was a 38-year-old male and his preoperative $\mathrm{HGH}$ value was $80 \mathrm{ng} / \mathrm{ml}$. His gonadotropins were all moderately hyperactive, but ACTH and Su4885 tests as well as his thyroid functions were both normal. His fasting blood sugar (FBS) was $128 \mathrm{mg} / \mathrm{dl}$ and it exhibited a diabetic pattern to GTT. Cryoablation was performed by a routine method at two different sites in the sella. Histology of the tumor revealed an eosinophilic adenoma. Postoperatively, HGH level rapidly dropped to $11.0 \mathrm{ng} / \mathrm{ml}$ and when he was re-examined one year after the operation, it 


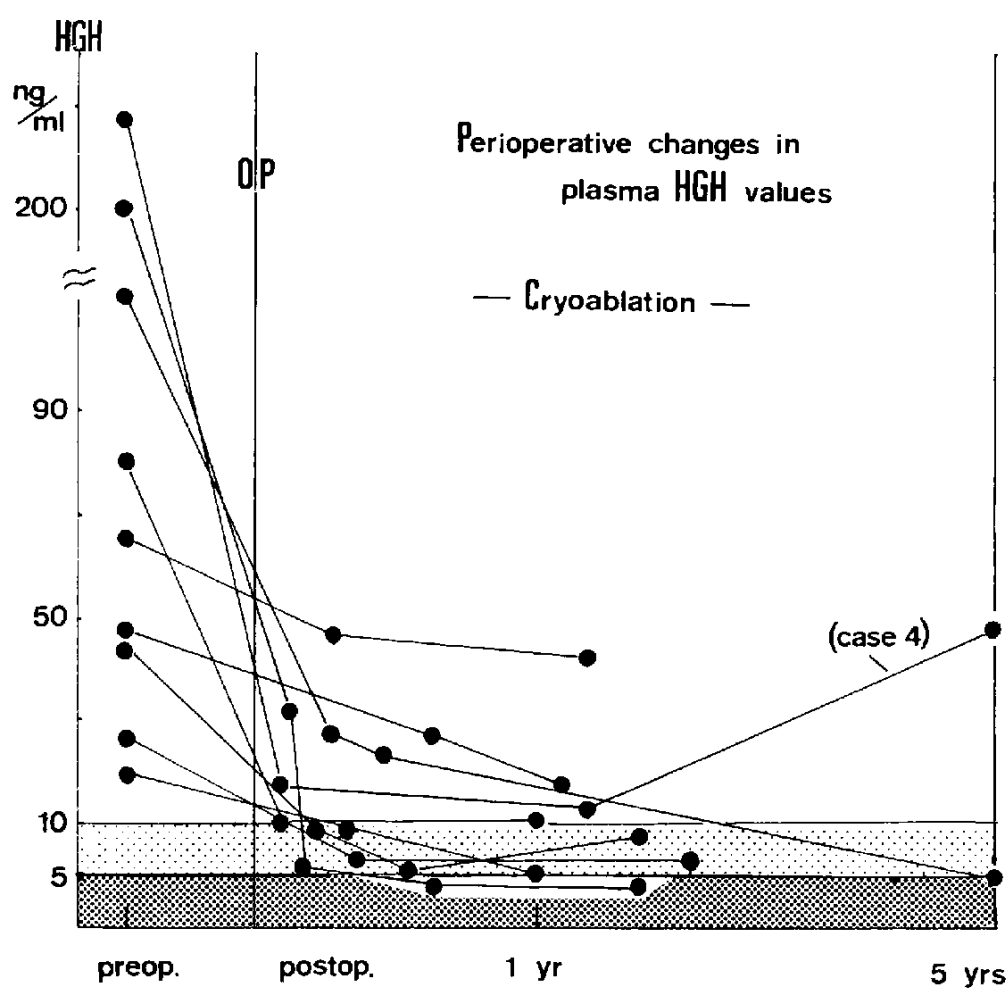

Fig. 1 Perioperative changes in plasma HGH values by transsphenoidal cryoablation. In 3 cases, postoperative $\mathrm{HGH}$ values decreased to less than $5 \mathrm{ng} / \mathrm{ml}$, and in 2 cases, they dropped to between 5 and $10 \mathrm{ng} / \mathrm{ml}$.

remained still slightly higher than $10 \mathrm{ng} / \mathrm{ml}$. His physical manifestations demonstrated much improvement after the surgery and other pituitary functions were all in the normal range. Although he still had slightly elevated FBS, he was not followed up for 5 years. When he visited us again with symptoms of diabetic retinopathy, his FBS was $171 \mathrm{mg} / \mathrm{dl}$ and his HGH level had risen to $48.2 \mathrm{ng} / \mathrm{ml}$. He was then operated on by microsurgery 6 years after the first operation. The residual tumor appeared mostly to be jellyish, well circumscribed and was totally removed except for a small part which was very fiberous and attached to the dura. His HGH level again dropped to $11.0 \mathrm{ng} / \mathrm{ml}$ after the surgery and remained at the same level for 3 years. $\mathrm{He}$ is still slightly diabetic but his condition is controllable.

\section{B) Oronasal rhinoseptal transsphenoidal micro- dissection}

The overall results are summarized in Tables 3 and 4. Clinical and endocrinological data for 10 out of 12 patients for whom surgery was performed at the Department of Neurosurgery at Tenri Hospital since 1967 were available for follow-up. Ages ranged from 14 to 56 years and there were 4 male and 6 female cases. All of the patients exhibited clinical and radiological manifestations of acromegaly, but no suprasellar extensions of the tumor were recognized in this series, except for 2 cases who showed minimum suprasellar extension of the mass. One case included in this series is the same patient who relapsed 5 to 6 years after cryogenic surgery. Five were diabetic and all 6 females were amenorrheal preoperatively.

Preoperative $\mathrm{HGH}$ levels ranged from 12.0 to $180.0 \mathrm{ng} / \mathrm{ml}$ with a mean value of $71.7 \mathrm{ng} / \mathrm{ml}$ and none of the cases showed normal responses to GTT or ITT, except for 2 cases who showed partly normal responses (Cases 3 and 7).

Preoperative pituitary functions were all in the normal range, except for one who displayed partial hyperactivities (Case 3, whose tumor was also gigantic). 
Table 3 Data of clinical features, plasma HGH levels, response of HGH to GTT or ITT and other pituitary functions before transsphenoidal microsurgical dissections. The term "partly responsive" to GTT or ITT (Cases 3,7) means that HGH value was responsive either to GTT or ITT. The term "partially hyperactive" in pituitary functions (Case 3) means that one or two pituitary hormones were hyperactive. Normal range of other pituitary functions means that almost all pituitary hormones were normal except for $\mathrm{HGH}$.

\begin{tabular}{|c|c|c|c|c|c|c|c|}
\hline No. & Name & Age & Sex & $\begin{array}{c}\text { Clinical } \\
\text { manifestations }\end{array}$ & $\underset{(\mathrm{ng} / \mathrm{ml})}{\mathrm{HGH}}$ & $\begin{array}{c}\text { GTT } \\
\text { ITT(HGH) }\end{array}$ & $\begin{array}{l}\text { Other } \\
\text { pituitary } \\
\text { functions }\end{array}$ \\
\hline 1. & Y.N. & 36 & $\mathbf{m}$ & $\begin{array}{l}\text { acromegalic } \\
\text { hypertensive }\end{array}$ & 180.0 & $\begin{array}{r}\text { no normal } \\
\text { response }\end{array}$ & $\begin{array}{l}\text { normal } \\
\text { range }\end{array}$ \\
\hline 2. & H.N. & 38 & f & $\begin{array}{l}\text { acromegalic } \\
\text { amenorrheal }\end{array}$ & 50.0 & $\begin{array}{l}\text { no normal } \\
\text { response }\end{array}$ & $\begin{array}{c}\text { normal } \\
\text { range }\end{array}$ \\
\hline 3. & S.K. & 14 & $\mathrm{f}$ & $\begin{array}{l}\text { acromegalic } \\
\text { gigantic } \\
\text { amenorrheal }\end{array}$ & 80.0 & $\begin{array}{l}\text { partly } \\
\text { poor } \\
\text { response }\end{array}$ & $\begin{array}{l}\text { partially } \\
\text { hyperactive }\end{array}$ \\
\hline 4. & M.K. & 55 & $\mathbf{m}$ & $\begin{array}{c}\text { acromegalic } \\
\text { D.M. }(+)\end{array}$ & 12.0 & $\begin{array}{l}\text { no normal } \\
\text { response }\end{array}$ & $\begin{array}{l}\text { normal } \\
\text { range }\end{array}$ \\
\hline 5. & H.S. & 32 & $\mathbf{m}$ & $\begin{array}{l}\text { acromegalic } \\
\text { D.M. }(+) \\
\text { hypertensive }\end{array}$ & 25.0 & $\begin{array}{l}\text { no normal } \\
\text { response }\end{array}$ & $\begin{array}{l}\text { normal } \\
\text { range }\end{array}$ \\
\hline 6. & T.F. & 56 & f & $\begin{array}{l}\text { acromegalic } \\
\text { D.M. }(+) \\
\text { amenorrheal }\end{array}$ & 39.0 & $\begin{array}{l}\text { no normal } \\
\text { response }\end{array}$ & $\begin{array}{c}\text { normal } \\
\text { range }\end{array}$ \\
\hline 7. & R.U. & 38 & f & $\begin{array}{l}\text { acromegalic } \\
\text { amenorrheal }\end{array}$ & 38.0 & $\begin{array}{l}\text { partly } \\
\text { responsive }\end{array}$ & $\begin{array}{l}\text { normal } \\
\text { range }\end{array}$ \\
\hline 8. & R.O. & 26 & f & $\begin{array}{l}\text { acromegalic } \\
\text { D.M. }(+) \\
\text { amenorrheal }\end{array}$ & 165.0 & $\begin{array}{l}\text { no normal } \\
\text { response }\end{array}$ & $\begin{array}{l}\text { normal } \\
\text { range }\end{array}$ \\
\hline 9.* & K.M. & 44 & $\mathrm{~m}$ & $\begin{array}{l}\text { acromegalic } \\
\text { D.M. }(+) \\
\text { hypertensive }\end{array}$ & 48.2 & $\begin{array}{l}\text { no normal } \\
\text { response }\end{array}$ & $\begin{array}{l}\text { normal } \\
\text { range }\end{array}$ \\
\hline 10. & Y.H. & 44 & $\mathrm{f}$ & $\begin{array}{l}\text { acromegalic } \\
\text { amenorrheal }\end{array}$ & 80.0 & $\begin{array}{l}\text { no normal } \\
\text { response }\end{array}$ & $\begin{array}{l}\text { normal } \\
\text { range }\end{array}$ \\
\hline
\end{tabular}

*A case recurred about 5 years after cryoablation D.M.: Diabetes mellitus

Postoperative follow-up periods varied between 3 months and 7 years (average 52 months). Clinical remissions were noted in all the cases, except for one (Case 8) and postoperative $\mathrm{HGH}$ levels ranged from 2.4 to 36.4 $\mathrm{ng} / \mathrm{ml}$ during the follow-up periods. In 4 cases, $\mathrm{HGH}$ level dropped to less than $5 \mathrm{ng} / \mathrm{ml}$. In another 4 cases, it was between 5 and $10 \mathrm{ng} / \mathrm{ml}$ and in the remaining 2 cases, HGH level was more than $10 \mathrm{ng} / \mathrm{ml}$. Four cases out of 10 revealed immediate postoperative drop in $\mathrm{HGH}$ level to less than $10 \mathrm{ng} / \mathrm{ml}$. In another 4 cases, HGH value gradually decreased to less than 10 $\mathrm{ng} / \mathrm{ml}$ within a couple of months, except for one in whom it took about 5 years (Fig. 2). All the cases did not respond normally to GTT or ITT, except for one with microadenoma (Case 7) who showed partly normal response even preoperatively.

Postoperative pituitary functions were preserved in 4 cases, partially but slightly reduced in one (Case 8 ), and totally but slightly reduced in 5 cases, although 2 cases of these (Cases, 2 and 3) were gradually restored to normal during the follow-up periods. One female case with microadenoma had menses again one year after the operation (Case 7). Three cases were still slightly diabetic but they were all controllable. Transient diabetes insipidus developed in 2 cases and one case (Case 6) died of meningitis 3 months 
Table 4 Data of postoperative changes in $\mathrm{HGH}$ and other pituitary functions after microsurgical hypophysectomy. The term "partially reduced" in pituitary functions (Case 8) means that one or two of pituitary hormones were insufficient. Operative complications and histology of tumors are also described.

\begin{tabular}{|c|c|c|c|c|c|c|c|}
\hline No. & Name & $\begin{array}{l}\text { Clinical } \\
\text { remissions }\end{array}$ & $\underset{(\mathrm{ng} / \mathrm{ml})}{\mathrm{HGH}}$ & $\begin{array}{c}\text { GTT } \\
\text { ITT(HGH) }\end{array}$ & $\begin{array}{l}\text { Other } \\
\text { pituitary } \\
\text { functions }\end{array}$ & $\begin{array}{l}\text { Complica- } \\
\text { tions }\end{array}$ & Histology \\
\hline 1. & Y.E. & yes & 7.2 & $\begin{array}{l}\text { no normal } \\
\text { response }\end{array}$ & $\begin{array}{l}\text { slightly } \\
\text { reduced }\end{array}$ & no & not verified \\
\hline 2. & H.N. & $\begin{array}{l}\text { yes, but } \\
\text { amenorrheal }\end{array}$ & 2.4 & $\begin{array}{r}\text { no normal } \\
\text { response }\end{array}$ & $\begin{array}{l}\text { sl. reduced } \\
\text { but gradually } \\
\text { normalized }\end{array}$ & no & not verified \\
\hline 3. & S.K. & $\begin{array}{l}\text { yes, but } \\
\text { amenorrheal }\end{array}$ & 6.3 & $\begin{array}{l}\text { no normal } \\
\text { response }\end{array}$ & $\begin{array}{l}\text { sl. reduced } \\
\text { but gradually } \\
\text { normalized }\end{array}$ & no & acidophilic \\
\hline 4. & M.K. & $\begin{array}{l}\text { yes } \\
\text { D.M. }( \pm)\end{array}$ & 7.0 & $\begin{array}{l}\text { no normal } \\
\text { response }\end{array}$ & preserved & $\begin{array}{l}\text { D.I. }(+) \\
\text { transient }\end{array}$ & acidophilic \\
\hline 5. & H.S. & $\begin{array}{l}\text { yes } \\
\text { D.M. (-) }\end{array}$ & 1.0 & $\begin{array}{l}\text { no normal } \\
\text { response }\end{array}$ & $\begin{array}{l}\text { slightly } \\
\text { reduced }\end{array}$ & $\begin{array}{l}\text { D.I. }(+) \\
\text { transient }\end{array}$ & mixed type \\
\hline 6. & T.F. & yes & 9.2 & $\begin{array}{l}\text { no normal } \\
\text { response }\end{array}$ & preserved & meningitis & chromophobe? \\
\hline 7. & R.U. & $\begin{array}{l}\text { yes } \\
\text { menses }(+)\end{array}$ & 4.4 & $\begin{array}{l}\text { partly } \\
\text { normal } \\
\text { response }\end{array}$ & preserved & no & acidophilic \\
\hline 8. & R.O. & $\begin{array}{l}\text { partially yes } \\
\text { amenorrheal }\end{array}$ & 36.4 & $\begin{array}{r}\text { no normal } \\
\text { response }\end{array}$ & $\begin{array}{l}\text { partially } \\
\text { slightly } \\
\text { reduced }\end{array}$ & no & acidophilic \\
\hline 9. & K.M. & $\begin{array}{l}\text { yes } \\
\text { D.M. }( \pm)\end{array}$ & 11.0 & $\begin{array}{r}\text { no normal } \\
\text { response }\end{array}$ & preserved & no & not verified \\
\hline 10. & Y.H. & $\begin{array}{l}\text { yes, but } \\
\text { amenorrheal }\end{array}$ & 4.5 & $\begin{array}{l}\text { no normal } \\
\text { response }\end{array}$ & $\begin{array}{l}\text { slightly } \\
\text { reduced }\end{array}$ & no & mixed type \\
\hline
\end{tabular}

D.M.: Diabetes mellitus

D.I.: Diabetes insipidus

after the surgery. ${ }^{12,23,24)}$

\section{Brief review of the non-curable case after micro-} surgery

Case 8 was a 26 -year-old female ${ }^{3)}$ who was amenorrheal and slightly diabetic (FBS was $131 \mathrm{mg} / \mathrm{dl}$ ). Her preoperative $\mathrm{HGH}$ level was $165 \mathrm{ng} / \mathrm{ml}$ and was poorly responsive to ITT but not responsive to GTT. Her HGH level was elevated after administration of both $\mathrm{LHrH}$ and TRH. She had a ballooned sella with minimum suprasellar extension of the tumor verified by pneumoencephalogram. Angiogram revealed that bilateral carotid arteries were deviated medially into the sella on antero-posterior projection. ${ }^{10)}$ At surgery, evacuation of the tumor was incomplete, since portions of the tumor behind the carotid arteries remained unresected. Portions which extended suprasellarly were completely removed. Histology of the tumor was acidophilic adenoma. Postoperative $\mathrm{HGH}$ value was still around $17.4-27.3 \mathrm{ng} / \mathrm{ml}$, also poorly responsive to ITT, but not to GTT, and again it was responsive to both $\mathrm{LHrH}$ and TRH. Her pituitary functions remained unchanged. After she received radiation therapy (4400 rads), her HGH level decreased transiently to less than $10 \mathrm{ng} / \mathrm{ml}$ but rose again within a couple of months and her FBS also rose to $152 \mathrm{mg} / \mathrm{dl}$. About one year after the first operation, a second exploratory operation was contemplated to remove possibly remaining tumor and, at the surgery, tumor-like tissues behind both carotid arteries were well cleaned out. Her HGH level, however, was still higher than normal level after the surgery and always fluctuated between $16-49.4 \mathrm{ng} / \mathrm{ml}$ for more than 3 years. Other pituitary functions all remained unchanged except for slight reduction in $\mathbf{L H}$ and FSH and she is still amenorrheal. 


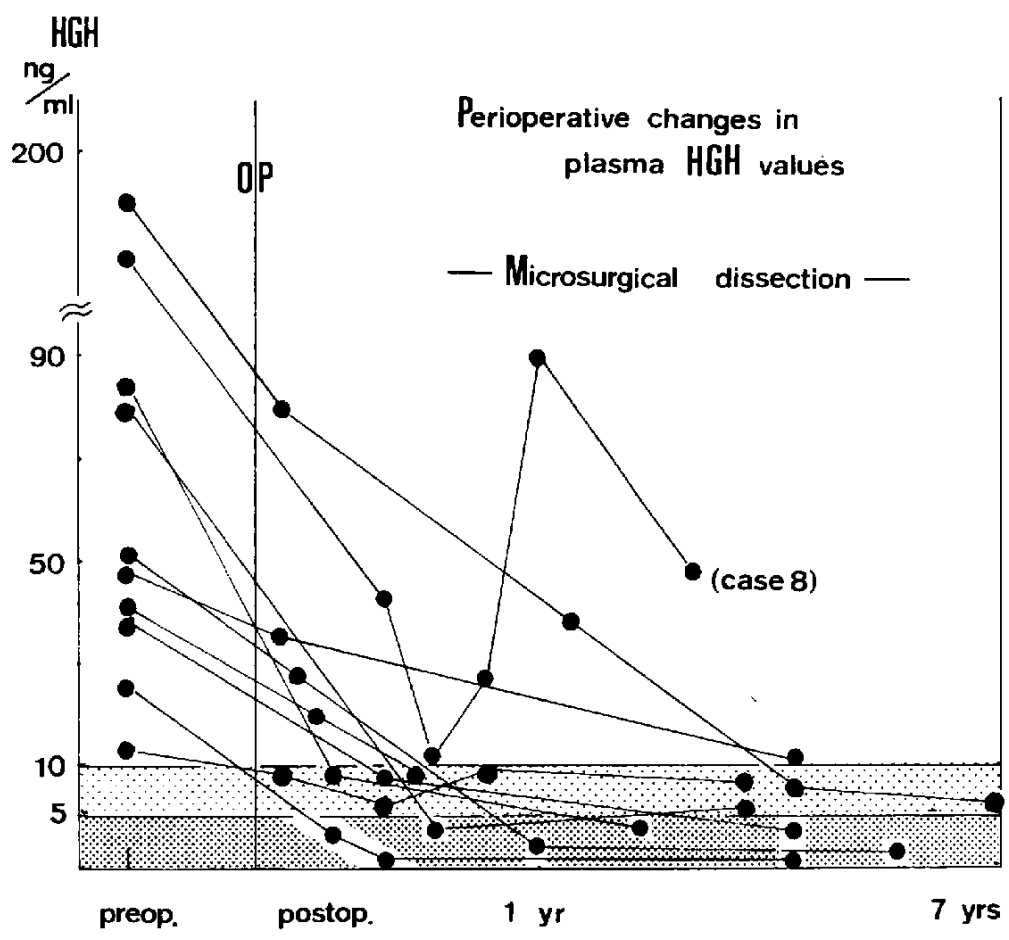

Fig. 2 Perioperative changes in plasma HGH values by transsphenoidal microsurgical dissection. In 4 cases, postoperative $\mathrm{HGH}$ levels decreased to less than $5 \mathrm{ng} / \mathrm{ml}$, and in 4 cases, they dropped to between 5 and $10 \mathrm{ng} / \mathrm{ml}$.

\section{Discussion}

Although various methods for the treatment of acromegaly have been reported in the past, the following two methods; transsphenoidal cryoablation and microsurgical dissection of the functioning pituitary adenoma, are now well established. Controversial opinions concerning the operative effects for satisfactory reduction in $\mathrm{HGH}$ and postoperative preservation of normal pituitary functions, however, prevail between the preference of these two methods. Also, as mentioned previously, precise descriptions that compare and discuss results of these two methods are not available.

\section{Postoperative changes in $H G H$ level}

The authors believe that total resection or destruction of tumor tissue is mandatory for the complete cure of acromegaly, as even a small residual tumor is sufficient to maintain hyperhormonemia. The precise level of $\mathrm{HGH}$ which may be regarded as a "cure" of acromegaly is still open to question. We agree with the opin- ions of Derome ${ }^{5)}$ and Leavens et al. ${ }^{17)}$ concerning the estimation of postoperative $\mathrm{HGH}$ level. They state that "cure" is when the level of $\mathrm{HGH}$, as a basal or 60 minutes after hyperglycemia, is less than $5 \mathrm{ng} / \mathrm{ml}$. "Failure" is more than $10 \mathrm{ng} / \mathrm{ml}$ and "intermediate" is between 5 and $10 \mathrm{ng} / \mathrm{ml}$. According to their opinions, it is not certain whether treatment is complete or not when the $\mathrm{HGH}$ values are higher than $5 \mathrm{ng} / \mathrm{ml}$ after the operation. As mentioned in the results of cryosurgery, 3 cases were cured, 2 cases were intermediate and 4 cases were non-effective. Whereas in microsurgery, 4 cases were cured, 4 cases were intermediate and 2 cases were not cured. When we reviewed our results using the two surgical methods, estimating postoperative HGH level similar to Derome's method, the outcome of operations were more satisfactory in the microsurgery group than in the cryosurgery group.

By microsurgery, we have better chances of removing the tumor tissue totally under the aid of an operative microscope and occasionally, we are also able to remove the intrapituitary microadenoma selectively whose complete resec- 
tion promises satisfactory reduction of $\mathrm{HGH}$ without damaging normal pituitary functions.

On the contrary, by cryogenic surgery, we cannot thoroughly estimate the ensuing freezing effect of the pathological tissue, although we can examine the size or extension of the lesion made by deep freezing. ${ }^{2,14)}$ We are also yet not sure whether or not intrapituitary adenoma can be selectively frozen by this method. ${ }^{19)}$ Accordingly, as far as satisfactory reduction of postoperative HGH value is concerned, microsurgical dissection of the tumor can be said to be a more accurate and steady method. According to the foregoing reports, postoperative changes in $\mathrm{HGH}$ is much faster after microsurgical intervention while, on the other hand, with cryogenic surgery the postoperative drop in $\mathrm{HGH}$ is sometimes gradual or delayed. ${ }^{19)}$ As for the postoperative interval for reducing the HGH below the normal level, our studies showed that there were no significant differences between the two operative groups as almost half of the operated cases showed instant drop in $\mathrm{HGH}$ in each group.

Recurrent case and incurable case as judged by postoperative HGH levels

We experienced one case of recurrence (Case 1) in the cryogenic surgery group. Postoperatively, his $\mathrm{HGH}$ level was $11.0 \mathrm{ng} / \mathrm{ml}$ when examined immediately after and one year after the surgery. He was not followed up further, and recurrent elevation of $\mathrm{HGH}$ was observed about 5 years after the first operation. The authors believe that Derome's method of estimating postoperative value of $\mathrm{HGH}$ is accurate since this patient showed only a slightly higher HGH level than the "intermediate" level $(11 \mathrm{ng} / \mathrm{ml})$ for one year after the operation. According to Lüdecke et al. ${ }^{18)}$, recurrence occurs frequently during the first year after the operation, but we do not know the exact time our case really recurred. This case suggests that the postoperative value of $\mathrm{HGH}$ should be frequently followed up for a longer period in all cases whose $\mathrm{HGH}$ level was still higher than $5 \mathrm{ng} / \mathrm{ml}$ after the destructive procedure for the tumor tissue was taken.

We had one uncured case by microsurgery (Case 8). We believed that her postoperative HGH value which was higher than normal was perhaps due to a residual tumor behind the intrasellarly protruding carotid arteries, since we were able to completely remove only the other parts of the tumor. When we operated again one year later following irradiation, we found her intrasellar cavity to be surprisingly clear, and the remaining tissue behind the carotid arteries was verified as histologically nontumorous. ${ }^{27)}$ Postoperative $\mathrm{HGH}$ value was, however, unsatisfactory and elevated again by administration of both $\mathrm{LHrH}$ and TRH although stimulation of $\mathrm{HGH}$ secretion by $\mathrm{LHrH}$ was denied in female by Rubin et al. ${ }^{25)}$ It was strange, however, that her other pituitary functions all remained normal even after two operations and irradiation except for slight reduction in basal $\mathrm{LH}$ and $\mathrm{FSH}$ values which were reactive to $\mathrm{LHrH}$ stimulation. Since her $\mathrm{HGH}$ value was always fluctuating above the normal level and rose persistently after administration of both LHrH and TRH, her operative results might indicate either the presence of residual tumor cells left behind, possibly outside of the sellar cavity, or abnormal response of the remaining HGH-producing tissue, but we have no clearcut explanation for that. ${ }^{15,26,28)}$

\section{Preservation of normal pituitary functions}

In the surgery of acromegaly, the reduction of $\mathrm{HGH}$ value is usually manageable but preservation of normal pituitary function is more problematic. It is always mandatory to remove the tumor completely and evacuate the sellar cavity without sacrificing recognizable anterior pituitary. It is surprising, however, that postoperative hypopituitarism was not so severe or sometimes partial even after presumably total resection of all anterior pituitary. Considerably normal function was retained with satisfactory reduction of HGH level and, additionally, insufficient pituitary functions gradually returned to normal in the follow-up periods in some cases probably due to regeneration of normal pituitary tissue. ${ }^{4,19)}$ As for the preservation of normal pituitary function, Lüdecke et al. ${ }^{18)}$ reported that in almost half of their cases, adenohypophyseal function was retained in "indistinct" operations. Also in $27 \%$ of their cases, active pituitary function was found even after "non-selective" radical excision. This confirms the hypothesis that complete removal of anterior pituitary can rarely be achieved during surgery since normal pituitary is compressed to the periphery of the sella by the tumor itself ${ }^{19)}$ 
and adherent to the dura it can escape total removal. ${ }^{27)}$

Microsurgical dissection may allow the surgeon to remove selectively the intrapituitary microadenoma and also to identify remnants of the normal pituitary tissue, ${ }^{10,12)}$ thereby ensuing preservation of normal pituitary function. In several cases, however, we had difficulties to find and distinguish normal and pathological pituitary tissues reliably even under the operative microscope. ${ }^{6,10)}$ The point of operation in microsurgery is to perform "probably selective" removal of the pathological tissue, since thoroughly selective removal of the tumor would have no problem for preservation of pituitary functions. And when we cannot differentiate normal and pathological pituitary tissues adequately, the decision has to made as to whether or not to risk leaving dubious tissues behind ${ }^{16)}$ or to overexcise normal pituitary tissues, depending upon the age, or the sexual capacity and the severity of the clinical syndrome of the patients. ${ }^{17)}$ Our postoperative data of pituitary functions after microsurgical dissection showed hypopituitarism soon after operation, probably due to overexcision of normal pituitary tissue.

Damage to the normal pituitary functions by cryogenic surgery cannot really be estimated during surgery and also we cannot really forecast the future change in pituitary functions since we have no idea whether this deep freezing technique has a selectivity to the pathological tissue or not. No reports can be found clearly describing such selective nature of deep freezing in cryogenic surgery. In reviewing our results of cryosurgery, however, there were no definite discrepancies between satisfactory reduction of HGH and preservation of normal pituitary functions in the effective cases. ${ }^{4,6)}$ This fact suggests that, the tumor tissue usually lie in the center of sellar cavity and this tissue might be frozen "selectively" by the cryogenic probe, hence the tip of the probe is usually set in the center of the sella.

Judging from our results, although the number of cases is limited, the authors believe that there are no significant differences in changes of postoperative pituitary functions between each of these surgery groups. We also do not have to pay too much attention for preservation of pituitary functions as long as we put the tip of cryogenic probe at the right site in the sella in cryogenic surgery, and if we perform "complete" total evacuation of the sellar cavity in microsurgery.

\section{Complications}

There were no significant differences in the incidences of operative complications in each operative method. These complications were not problematic except for one case who had a history of chronic sinusitis preoperatively and died of meningitis after microsurgical operation.

\section{Conclusion}

After eradication of secreting pituitary adenoma either by cryogenic surgery or by microsurgical intervention, the patients usually have satisfactory clinical remissions. There are, however, little correlations between $\mathrm{HGH}$ levels and clinical activity. The authors believe it appropriate to use severe criterias for estimating postoperative HGH levels according to Derome's method. ${ }^{5)}$ When estimating our follow-up data of $\mathrm{HGH}$ in each method, the microsurgical intervention is more steady and satisfactory in lowering HGH level than cryogenic surgery. As for the postoperative preservation of normal pituitary functions, there are no definite differences between these operative methods. Using the microsurgical technique, it is much more feasible to remove intrapituitary adenoma selectively, but conversely, with this technique, postoperative hypopituitarism is likely to occur in case of "probably selective" resection of pituitary tumor. Since postoperative hypopituitarism is not severe, and sometimes temporary, exogenous hormone administration is required in a few cases. The authors believe that all dubious tissue should be resected together with the tumor tissue by microsurgical technique for complete cure of acromegaly. It is concluded that, as far as a radical treatment of acromegaly is concerned, the microsurgical resection is more preferable than cryogenic surgery for hypersecreting pituitary adenoma.

\section{Acknowledgments}

The authors are indebted to Dr. Hiroo Imura for his advice and encouragement during this work. Appreciation is expressed to Drs. Shunichiro Kurata and Hiroshi Tsuji for their as- 
sistance in examining the materials.

\section{References}

1) Cooper, I. S.: Cryogenic surgery: New method of destruction or extirpation of benign or malignant tissues. $N$ Eng $J$ Med 268: 743-749, 1963.

2) Cooper, I. S.: Cryogenic surgery in the geriatric patients. $J$ Am Geriatr Soc 12: 813-855, 1964.

3) Crowell, R. M., Kjellberg, R. N., Kliman, B. and Kornblith, P. L.: Invasive pituitary tumor producing acromegaly, extreme elevation of growth hormone, and abnormal growth in tissue culture. Neurochirurgia 17: 129-135, 1974.

4) Dashe, A. M., Solomon, D. H., Rand, R. W., Frasier, S. D., Brown, J. and Spears, I.: Stereotaxic hypophyseal cryosurgery in acromegaly and other disorders. JAMA 198: 591-596, 1966.

5) Derome, P.: Personnal communication, 1976

6) DiTullio, M. V., Jr. and Rand, R. W.: Efficacy of cryohypophysectomy in the treatment of acromegaly. $J$ Neurosurg 46: 1-11, 1977.

7) Guiot, G.: Transsphenoidal approach in surgical treatment of pituitary adenomas: General principles and indications in nonfunctioning adenomas. pp 159-178, In Kohler, P. O. and Ross, G. T. (eds): Diagnosis and Treatment of Pituitary Tumor. Excerpta Medica, Amsterdam, 1973.

8) Handa, H., Tani, E., Takase, T., Hashi, K., Shimizu, Y. and Takeuchi, J.: Cryogenic hypophysectomy. Saishin-Igaku (Jap) 23: 1016-1028, 1968.

9) Hardy, J. and Wigser, S. M.: Transsphenoidal surgery of pituitary fossa tumors with televised radiofluoroscopic control. $J$ Neurosurg 23: 612-619, 1965.

10) Hardy, J.: Transsphenoidal microsurgery of the normal and pathological pituitary. pp 185-217, In Ojemann, R. G. (ed): Clinical Neurosurgery. Vol. 16, The Williams \& Wilkins Company, Baltimore, 1968.

11) Hardy, J.: Microneurosurgery of the hypophysis-a subnasal transsphenoidal approach with television magnification and televised radiofluoroscopic control. pp 87103, In Rand, R. W. (ed): Microneurosurgery. The C. V. Mosby Company, St. Louis, 1969.

12) Hardy, J.: Transsphenoidal hypophysectomy. $J$ Neurosurg 34: 582-594, 1971.
13) Hirsch, O.: Pituitary tumors a borderland between cranial and trans-sphenoidal surgery. $N$ Eng J Med 254: 937-939, 1956.

14) Holden, H. B.: Cryosurgery in E.N.T. practice. $J$ Laryngol Otol 86: 821-827, 1972.

15) Irie, M. and Tsushima, T.: Increase of serum growth hormone concentration following thyrotropin-releasing hormone injection in patients with acromegaly or gigantism. $J$ Clin Endocrinol Metab 35: 97-100, 1972.

16) Lazorthes, Y.: Utilisation de la chloropromazine et de la microchirurgie transsphénoidale dans le traitment de l'acromegalie. Neurochirurgie (Paris) 19: 603-610, 1973.

17) Leavens, M. E., Samaan, N. A., Jesse, R. H., Jr. and Byers, R. M. : Clinical and endocrinological evaluation of 16 acromegalic patients treated by transsphenoidal surgery. $J$ Neurosurg 47: 853-860, 1977.

18) Lüdecke, D., Kautzky, R., Saeger, W. and Schrader, D.: Selective removal of hypersecreting pituitary adenoma? Acta Neurochirurgica 35: 27-42, 1976.

19) Maddy, J. A., Winternitz, W. W., Norrel, H., Quillen, D. and Wilson, C. B.: Acromegaly: Treatment by cryoablation. Ann Intern Med 71: 497-505, 1969.

20) Rand, R. W., Dashes, A. M., Paglia, D. E., Conway, L. W. and Solomon, D. H.: Stereotaxic cryohyphysectomy. JAMA 189: 255-259, 1964.

21) Rand, R. W.: Cryosurgery of the pituitary in acromegaly: Reduced growth hormone levels following hypophysectomy in 13 cases. Ann Surg 164: 587-592, 1966.

22) Rand, R. W.: Hypophysectomy in endocrine disorders. pp 226-249, In Ojemann, R. G. (ed): Clinical Neurosurgery. Vol. 17, The Williams \& Wilkins Company, Baltimore, 1970.

23) Rand, R. W., Heuser, G. and Adams, D. A.: Ten-Year experience with stereotaxic cryohypophysectomy. pp 252-271, In Krayenbühl, H., Maspes, P. E. and Sweet, W. H. (eds): Progress in Neurological Surgery. Vol. 6, S. Karger, Basel, 1975.

24) Richards, S. H., Dalton, G., Forrest, A. M. P., Harris, P. and Ironside, W. M. S.: Hypophysectomy (Panel discussion). $J$ Laryngol Orol 85: 1274-1279, 1971.

25) Rubin, A. L., Levin, S. R., Bernstein, R. I., Tyrrell, J. B., Noacco, C. and Forsham, P. H.: Stimulation of growth hormone by luteinizing hormone-releasing hormone in active acromegaly. $J$ Clin Endocrinol Metab 37: 160-162, 1973. 
26) Samaan, N. A., Leavens, M. E. and Jesse, R. H.: Serum growth hormone and prolactin response to thyrotropin- releasing hormone in patients with acromegaly. $J$ Clin Endocrinol Metab 38: 957-963, 1974.

27) U, H. S., Wilson, C. B. and Tyrrell, J. B.: Transsphenoidal microhypophysectomy in acromegaly. $J$ Neurosurg 47: 840-852, 1977. 28) von Wild, K., Hoffman, F. D., Neubauer, M. and Althoff, P. H.: Hypophyseal function in the operative and postoperative phases after removal of pituitary tumours. Acta Neurochirurgica 35: 15-26, 1976, 